\title{
Ketrampilan Memainkan Recorder Melalui Model Kooperatif Tipe Jigsaw
}

\author{
Abdul Rozaq Fathin Khusairi ${ }^{1}$, Rully Aprilia Zandra ${ }^{2}$, Ninik Harini ${ }^{3}$ \\ 1,2,3Jurusan Seni dan Desain, Fakultas Sastra, Universitas Negeri Malang
}

\begin{abstract}
This research was conducted at Dau 1 Malang Middle School in the learning of art class VII culture. It is known that learning outcomes in class VII-B are under the KKM (75). The total number of students who completed it was only $35.48 \%$ in the skill of playing a musical instrument recorder. The study aimed to improve the quality of learning outcomes in playing a musical instrument recorder in class VII-B in SMP Negeri 1 Dau through the application of atype cooperative learning model jigsaw. The research method used was Classroom Action Research, the approach used was descriptive qualitative, the research subjects were 31 students. The study was conducted in 2 cycles with the procedure covering four stages, namely planning, action, observation, reflection.Data collection techniques use observation, interview, documentation, and test techniques. The results of the first cycle of students whose grades were completed above the KKM were $54.83 \%$, in the second cycle students whose grades were completed above the KKM amounted to $90.3 \%$. It can be concluded that the application of thetype cooperative learning model jigsaw can improve student learning outcomes up to $90.3 \%$.
\end{abstract}

Keywords: Musical Instrument Recorder Skill, TypeCooperative Learning Model Jigsaw

\begin{abstract}
Abstrak
Penelitian ini dilaksanakan di SMP Negeri 1 Dau Kabupaten Malang pada pembelajaran seni budaya kelas VII. Diketahui hasil belajar dikelas VII-B berada dibawah KKM (75). Jumlah siswa yang tuntas hanya 35,48\% pada materi keterampilan memainkan alat musik recorder. Penelitian bertujuan untuk meningkatkan kualitas hasil belajar memainkan alat musik recorder pada kelas VII-B di SMP Negeri 1 Dau melalui penerapan model pembelajaran kooperatif tipe jigsaw. Metode penelitian yang digunakan adalah Penelitian Tindakan Kelas, pendekatan yang digunakan kualitatif deskriptif, subjek penelitian berjumlah 31 siswa. Penelitian dilakukan dalam 2 siklus dengan prosedur meliputi 4 tahap yaitu Perencanaan, pelaksanaan tindakan, observasi, refleksi.Teknik pengumpulan data menggunakan teknik observasi, wawancara, dokumentasi,dan tes. Hasil penelitian siklus I siswa yang nilainya tuntas di atas KKM sejumlah 54,83\%, Pada siklus II siswa yang nilainya tuntas di atas KKM sejumlah 90,3\%. Dapat disimpulkan bahwa penerapan model pembelajaran kooperatif tipe jigsaw dapat meningkatkan hasil belajar siswa hingga mencapai 90,3\%.
\end{abstract}

Kata kunci: Keterampilan Memainkan Alat Musik Recorder, Model Pembelajaran Kooperatif Tipe Jigsaw

\section{Pengantar}

Pembelajaran seni budaya merupakan pembelajaran yang menuntut siswa untuk berkreativitas sehingga dalam pelaksanaanya guru seni juga dituntut untuk memiliki kreativitas dan menguasai skill dalam bekesenian, serta dapat menerapkan strategi dalam pelakasanaan pembelajaran. Salah satunya yaitu dengan memilih penerapan model yang tepat untuk proses pembelajaran seni budaya demi tercapainya tujuan pembelajaran. Teknik penyajian pelajaran adalah teknik penyajian yang dikuasai guru untuk mengajar atau menyajikan bahan pelajaran kepada siswa didalam kelas, agar pelajaran tersebut daapat ditangkap, dipahami dan digunakan oleh 
siswa dengan baik menurut (Roestiyah, 2008: $1)$.

Pembelajaran seni budaya pada umumnya merupakan pelajaran yang menyenangkan karena melalui pembelajaran seni siswa dapat mengekspresikan ide-ide, keterampilan dan pemikiran estetika. Kenyataannya penyelenggaraan pendidikan seni budaya khususnya seni musik dengan Kurikulum 2013 di SMPN 1 Dau kabupaten Malang kelas VII-B pada kompetensi dasar 4.4 memainkan alat musik ansamble sejenis dan campuran, terdapat beberapa permasalahan dalam proses pembelajaran. Berdasarkan observasi yang telah dilakukan oleh peneliti pembelajaran seni budaya di kelas VII-B tersebut masih kurang memotivasi minat siswa sehingga siswa kurang aktif pada saat pembelajaran khususnya pada materi memainkan alat musik recorder.

Kelas VII-B merupakan kelas yang hasil belajarnya pada materi memainkan alat musik recorder paling rendah dari kelas lainnya. Jumlah siswa di kelas VII-B terdiri 31 siswa, dari nilai rata-rata siswa kelas VIIB yang mendapatkan nilai di atas KKM sekitar 35\% dan siswa yang mendapatkan nilai di bawah KKM sekitar $65 \%$, jadi dari identifikasi hasil belajar siswa menunjukan bahwa kelas tersbut masih perlu di berikan peningkatan dalam proses pembelajaran. Adapun permasalahan yang terjadi dikelas tersebut diantaranya 1 . pada saat guru menerangkan tentang pembelajaran seni musik siswa terlihat tidak aktif dalam mengikuti pelajaran, 2 . banyak siswa yang tidak memperhatikan penjelasan guru, 3. ketika pelajaran berlangsung siswa mengobrol sendiri, 4. penyelesaian tugas tidak tepat waktu. Hal tersebut akan berdampak pada hasil belajar siswa.

Permasalahan di atas akan berdampak pada ketuntasan atau hasil belajar siswa pada materi pembelajaran bermain recorder. Hal utama yang harus dicermati oleh guru adalah bagaimana membuat suasana pembelajaran menjadi aktif dan menyenangkan sehingga dapat meningkatkan siswa dalam mencapai hasil belajar. Sebagai solusi dari permasalahan tersebut, peneliti dan juga guru di kelas VIIB SMPN 1 Dau kabupaten Malang, akan menggunakan model pembelajaran kooperatif tipe Jigsaw dengan materi memainan alat musik recorder.

Penerapan kooperatif jigsaw di pilih dalam penelitian tindakan kelas ini diharapkan dapat membuat siswa lebih aktif dalam pelaksanaan pembelajaran dan dapat meningkatkan hasil belajar siswa. Berdasarkan teori di atas, nantinya dalam penerapannya model kooperatif jigsaw akan dibuat suatu kelompok-kelompok kecil yang mana disetiap kelompok kecil memiliki anggota ahli. Adanya kelompok ahli akan memudahkan Guru dalam mengajar, karena kelompok ahli yang bertugas menjelaskan materi kepada teman-temannya atau kelompoknya.

Pembelajaran kooperatif model Jigsaw yang akan di terapkan, siswa diajak lebih aktif dalam memahami suatu materi pelajaran dengan cara berkelompok khususnya pelajaran seni musik, karena pembelajaran menggunakan model kooperatif tipe jigsaw mempunyai sistem pembelajaran menggunakan model kooperatif yang terdiri dari beberapa anggota dalam satu kelompoknya yang bertanggungjawab atas penguasaan materi belajar dan mampu mengerjakan materi tersebut kepada anggota lain dalam kelompoknya menurut Julianto, dkk (2011 : 31).

Berdasarkan uraian masalah diatas mendorong peneliti untuk melakukan penelitian tentang "penerapan model pembelajaran kooperatif tipe Jigsaw untuk meningkatkan keterampilan memainkan alat music recorder pada siswa kelas VII-B SMPN 1 Dau kabupaten Malang.

Unsur penting dalam pembelajaran cooperatif jigsaw pada umumnya saling 
bekerja sama, menimbulkan interaksi antar siswa dan tanggung jawab secara individu. Menurut Trianto (2010: 60) untuk mencapai hasil maksimal, terdapat lima unsur penting dalam pembelajaran kooperatif yaitu: 1 . Saling ketergantungan yang positif antar siswa, 2. Interaksi antar siswa yang semakin meningkat, 3. Tanggung jawab individual, 4. Keterampilan interpersonal dan kelompok kecil, 5. Proses kelompok.

Teknik mengajar Jigsaw sebagai model pembelajaran kooperatif dapat di gunakan dalam mengembangkan membaca, menulis, mendengarkan atau mempraktekkan. Dalam buku Modul Umum Pendidiakan dan Profesi Guru Sutijono (2011:17) menyatakan bahwa pembelajaran kooperatif tipe Jigsaw adalah suatu tipe pembelajaran kooperatif yang terdiri dari beberapa anggota dalam satu kelompok yang bertanggug jawab atas penguasaan materi belajar dan mampu mengajarkan materi tersebut kepada anggota lain dalam kelompoknya.

\section{Alat Musik Recorder}

Recorder merupakan alat musik melodis yang sumber bunyinya berasal dari tekanan udara (aerophone) dan cara memainkan dengan cara ditiup. Recorder atau seruling umumnya digunakan untuk pengajaran di sekolah. Jenis recorder yang sering digunakan adalah recorder sopran, disamping itu recorder sopran ada juga recorder sopranino dan recorder alto (Wahyu Purnomo, 2009:71).

Bagian-bagian recorder sopran adalah: 1) Bagian kepala, sebagai sumber tiupan untuk menimbulkan bunyi, 2) Bagian tubuh / badan, 3) Bagian kaki. Bagian tubuh dan kaki adalah sebagai sumber nada dan berguna untuk menyelaraskan nada (Wahyu Purnomo, 2009:71).
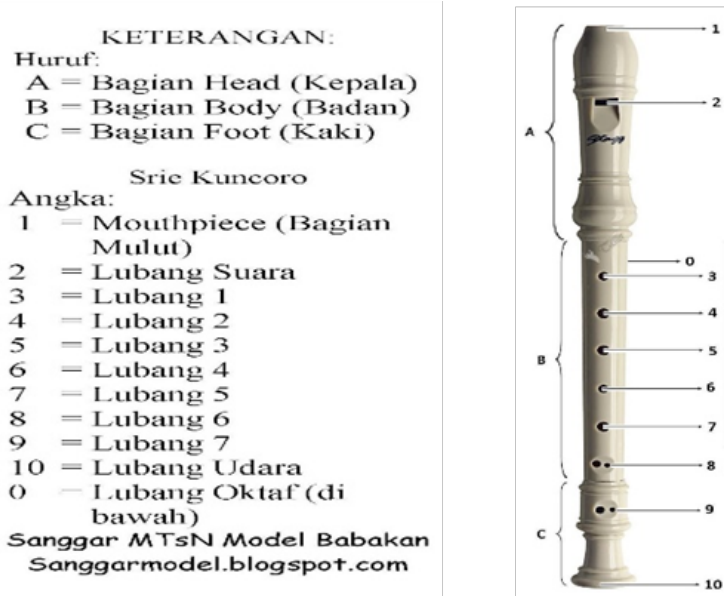

Gambar 1. Bagian Recorder (Sumber: https://caryntiong.wordpress.com/bagianrec order/)

Posisi Jari Pada Recorder

Tangan kiri:1) Ibu jari untuk menutup lubang nol, 2) Telunjuk untuk menutup lubang satu, 3) Jari tengah untuk menutup lubang dua, 4) Jari manis untuk menutup lubang tiga, 5) Jari kelingking tidak digunakan.

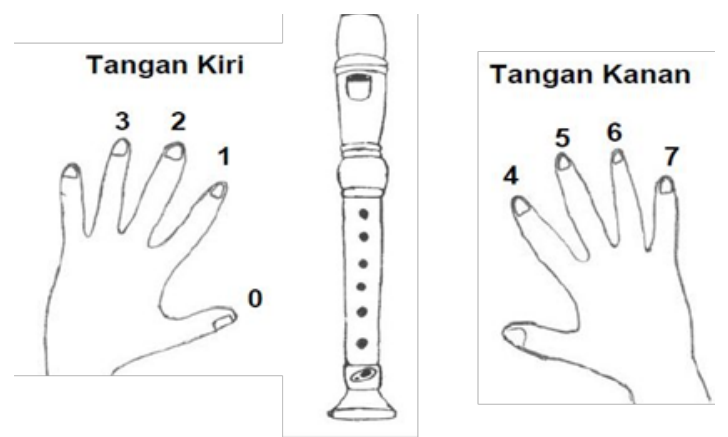

Gambar 2. Posisi Jari Pada Recorder (Sumber: https://caryntiong.wordpress.com/recorder/)

Tangan kanan: 1) Ibu jari untuk menahan badan recorder, 2) Jari Telunjuk untuk menutup lubang empat, 3) Jari tengah untuk menutup lubang lima, 4) Jari manis untuk menutup lubang enam, 5) Jari kelingking menutup lubang tujuh.

Teknik Memainkan

Teknik memainkan alat musik recorder adalah sebagai berikut: 1) Letakkan sumber tiupan (mounthpiece) di antara dua bibir, jangan terlalu keluar, jangan terlalu 
masuk atau pun keluar, 2) Tangan kiri memegang bagian badan atas recorder dengan setiap jari menutup lubang-lubang tertentu, 3) Tangan kanan memegang bagian bawah badan recorder dengan tugas setiap jari menutup lubang-lubang nada tertentu, 4) Posisi recorder diarahkan ke depan dengan sudut $30-45$ derajat, 5) Posisi/sikap badan tegak menghadap ke depan, 6) Dada membusung dan kedua belah siku terangkat sehingga tidak menyentuh badan, 7) Pernafasan yang digunakan dalam meniup adalah pernafasan diafraghma, 8) Tiupan recorder seakan-akan ucapan TU, bukan HU atau FU.

Cara mengetahui tiupan yang baik adalah : (1) imajinasi meniup lilin, (2) meniup bola sabun, dan (3) meniup telapak tangan dengan rasa hangat, (Wahyu Purnomo, 2009: 73) Sedangkan posisi jari pada recorder akan menghasilkan nada-nada sebagai berikut: 1) Penjarian 0, 1 menghasilkan nada $\mathrm{B} / \mathrm{si}, 2$ ) Penjarian 0, 1, 2 menghasilkan nada A/la. 3) Penjarian 0, 1, 2, 3 menghasilkan nada G/sol, 4) Penjarian 0, 2 menghasilkan nada $C 2 /$ do tinggi, 5) Penjarian 2 menghasilkan nada D 2/re tinggi, 6) Penjarian 0, 1, 2, 3, 4 menghasilkan nada F/fa, 7) Penjarian 0, 1, 2, 3, 4, 5 menghasilkan nada E/mi, 8) Penjarian $0,1,2,3,4,5,6$ menghasilkan nada D/re, 9) Penjarian 0, 1, 2, 3, 4, 5, 6 dan 7 menghasilkan nada $\mathrm{C} /$ do.

Berkaitan dengan penelitian ini maka dari kajian teori diatas, alat musik recorder merupakan materi pembelajaran yang akan nantinya diajarkan kepada siswa sebagai instrumen peneliti untuk memperoleh data di lapangan.

Tempo

Secara umum Untuk menghasilkan nada-nada yang seirama, didalam tanda bermain musik terdapat tempo atau ketukan. Syafiq (2004:66) menjelaskan bahwa tempo adalah cepat lambatnya sebuah lagu atau instrumen, meskipun jenisnya sangat banyak, pada dasarnya tempo dibagi menjadi tiga jenis yaitu lambat, sedang, dan cepat.

Melodi

Melodi adalah susunan rangkaian nada (bunyi dengan getaran teratur) yang terdengar berurutan serta berirama dan mengungkapkan suatu gagasan atau ide (Jamalus, 1996:16). Melodi juga salah satu komponen musik yang di jadikan sebagai pembeda antara jenis lagu satu dengan lagu yang lain (Zandra, 2014 :77). Dalam penelitian ini, melodi memiliki pengertian nada-nada pokok tema lagu, sebagai contoh melodi lagu burung tantina.

\section{Metode}

Penelitian Tindakan Kelas (PTK) merupakan penelitian yang akan dilakukan dalam penelitian ini. Menurut Arikunto (2015: 2) Penelitian Tindakan Kelas (PTK) adalah suatu pencermatan terhadap kegiatan belajar berupa sebuah tindakan, yang sengaja dimunculkan dan terjadi dalam sebuah kelas bersama dalam bentuk kegiatan belajar mengajar untuk memperbaiki dan meningkatkan kondisi pembelajaran yang dilakukan. Penelitian Tindakan Kelas (PTK) yang dilakukan dalam penelitian ini yaitu tentang penerapan model pembelajaran kooperatif tipe Jigsaw untuk meningkatkan keterampilan memainkan alat music recorder pada siswa kelas VII-B SMPN 1 Dau kabupaten Malang. Bertujuan untuk meningkatkan keterampilan dalam memainkan alat musik recorder.

Pendekatan penelitian menggunakan pendekatan kualitatif deskriptif meskipun didalam penelitian terdapat juga data-data kuantitatif tetapi kemudian akan didiskripsikan untuk memvisualkan kondisi tertentu. Uraian data, baik itu sebelum, selama maupun sesudah tindakan peneliti lebih dominan dengan menggunakan pemaknaan pristiwa yang terjadi

Prosedur persiklus dapat dilihat pada gambar berikut: 


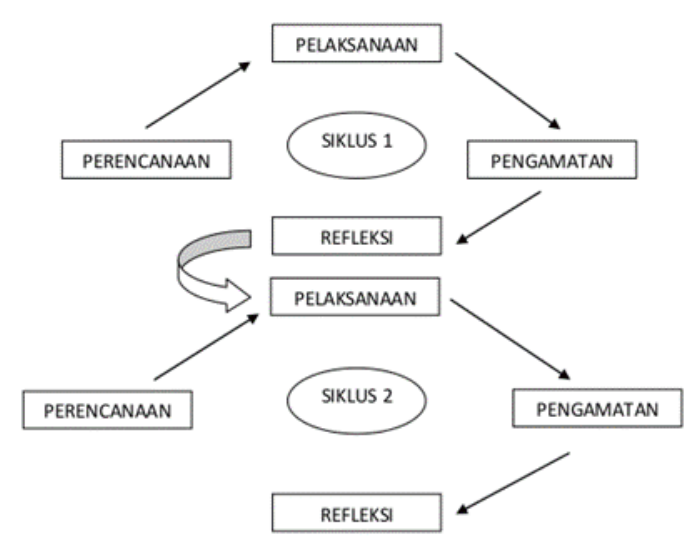

Bagan 3.1 Peta Konsep Alur Kegiatan PerSiklus ( Sumber: Arikunto, 2015: 42)

\section{Pembahasan}

Perapan model pembelajaran kooperatif tipe jigsaw ini dari pelaksanaannya terdiri dari kelompokkelompok kecil dibagi menjadi dua tipe kelompok yaitu kelompok inti (kelompok besar) dan kelompok ahli (kelompok yang harus menguasai materi). Hal ini sesuai dengan pernyataan Arikunto (2015: 158) bahwa model pembelajaran kooperatif Jigsaw dalam pelaksanaannya di bentuk kelompok-kemlompok kecil yang di dalamnya terdiri dari kelompok yang berbeda yang telah mempelajari sub bab materi yang sama bertemu dengan kelompok baru di namakan kelompok ahli, dan kelompok inilah yang nanti akan menjelaskan atau mengajari kelompok asal/kelompok inti.

Model pembelajaran kooperati tipe jigsaw berguna untuk mempermudah dalam keberahasilan penyampaian materi, pemahaman dan lebih memberikan motivasi kepada siswa agar dapat mencapai tujuan secara bersama, hal tersebut sesuai dengan pernyataan Sukidin, (2006:162) pembelajaran kooperatif adalah pemabelajaran yang memandang keberhasilan individu di orientasikan dalam keberhasilan dalam kelompok. Dalam hal ini, siswa bekerja sama dalam mencapai tujuan dan siswa berusaha keras membantu dan mendorong pada teman-temannya untuk bersama-sama berhasil dalam kelompok belajarnya.

Berikut pembahasan hasil penelitian masing- masing tahap yang dilaksanakan selama 2 siklus:

Pembahasan dalam siklus 1 meliputi 4 tahap yaitu: perencanaan, pelaksanaan, pengamatan dan refleksi. Masing-masing tahapan telah dijabarkan pada penerapan model pembelajaran kooperatif tipe jigsaw sebagai berikut

Perencanaan pada siklus I yang dilakukan dalam penelitian ini, di awali dengan tahap susunan rancangan pelaksanaan pembelajaran. Guru seni budaya di SMPN 1 Dau sebelum memulai pembelajaran, mempersiapkan rancangan pelaksanaan pembelajaran (RPP) sebagai pedoman dalam mengajar dengan materi teknik dasar memainkan alat musik recorder, sesuai dengan pernyataan Umar (2016:367), bahwa setiap guru wajib memiliki kopetensi pengembangan silabus dan RPP, sebab kopetensi tersebut sebagai bekal seorang guru dalam perencanaan proses kegiatan pembelajaran.

Guru dalam perencanaannya juga menyiapkan media pembelajaran berupa PPT dan recorder sebagai alat untuk membantu menyampaikan materi teknik dasar memainkan alat musik recorder dengan model kooperatif tipe jigsaw, hal ini sesuai dengan pernyataan Harini dkk (2018:279), Media pembelajaran merupakan salah satu perangkat yang sangat diperlukan di sekolah untuk membantu menyampaikan materi dalam pembelajaran.

Penerapan model kooperati tipe jigsaw dipilih sebagai strategi dari pemecahan masalah yang dituangkan dalam rancangan pelaksanaan pembelajaran. Model kooperatif jigsaw dalam penerapannya siswa sendiri yang akan menerangkan materi dan guru hanya sebagai vasilitator, yaitu dengan pembentukan kelompok diskusi yang terdiri dari kelompok besar dan kelompok ahli. Hal 
ini sesuai dengan pernyataan Sutijono (2011:82), model pembelajaran cooperative learning adalah salah satu model pembelajaran yang menempatkan siswa sebagai subjek pembelajaran (student oriented).

Pelaksanaan kegiatan penelitian pembelajaran pada siklus I menggunakan model kooperatif tipe jigsaw dengan materi teknik dasar keterampilan memainkan alat musik recorder. Materi keterampilan yang dimaksud disini yaitu keterampilan siswa dalam memainkan alat musik recorder yang benar dan sesuai aturan cara memainkan alat musik recorder, seperti halnya menurut Henny (2016:1088) mengartikan bahwa keterampilan adalah kecekatan, kecakapan, atau kemampuan untuk melakukan sesuatu dengan baik dan cermat. Keterampilan dalam bermain musik termasuk ke dalam indikator hasil belajar pada aspek spikomotorik dalam pembelajaran seni budaya.

Proses pelaksanaan pembelajaranya, memberikan pengorganisasian yaitu pembentukan kelompok kecil atara 4-5 anggota. Setiap kelompok memiliki kelompok ahli sebagai anggota yang meyampaikan materi kepada siswa atau kelompoknya, hal ini sesuai dengan pernyataan Sutijono, (2011:17) menyatakan bahwa pembelajaran kooperatif tipe Jigsaw adalah suatu tipe pembelajaran kooperatif yang terdiri dari beberapa anggota dalam satu kelompok yang bertanggug jawab atas penguasaan materi belajar dan mampu mengajarkan materi tersebut kepada anggota lain dalam kelompoknya.

Pengamatan dilakukan dengan mengamati keterampilan peserta didik selama proses pembelajaran berlangsung dan menilai aktifitas peserta didik dalam proses pembelajaran serta melihat perubahan sejauh apa perkembangan kognitif dan psikomotor peserta didik sesudah di terapkan model pembelajaran kooperatif tipe jigsaw, hal ini sesuai dengan pernyataan Arikunto (2015:36), Bahwa ada beberapa hal yang perlu diamati dalam tahap pengamatan meliputi keaktifan siswa belajar kondisi kelas dan hasil belajar siswa.

Proses pengamatan model pemebelajaran kooperatif tipe jigsaw pada siklus I pertemuan pertama membahas tentang teknik dasar memainkan alat musik recorder dengan materi penjarian, solmisai, teknik meniup dan kualitas. Pada pertemuan ke dua melanjutkan materi yang belum selesai pada pertemuan pertama. Dan pada pertemuan ketiga siswa mempraktekkan didepan secara berkelompok tentang materi yang sudah di pelajari.

Pada tahap siklus I pertemuan ke dua masih ada sebagian siswa terlihat tidak memperhatikan apa yang disampaikan oleh anggota tenaga ahli. Hal ini berakibat siswa tidak bisa memahami materi secara sungguh-sungguh. Tetapi pada siklus I ini sudah ada peningkatan hasil belajar siswa, terbukti dilihat dari empat aspek penilaian tentang penjarian, tempo, melodi dan kualitas suara yaitu siswa mampu melakukan dasar penjarian memainkan solmisasi dua tangga nada $\mathrm{C}$ dan $\mathrm{D}$ dengan lancar, siswa mampu mengikuti tempo dengan irama pada lagu secara keseluruhan sampai akir lagu, siswa mampu memainkan melodi lagu burung tantinya dengan sangat lancar, siswa mampu meniup recorder dengan kualitas suara tiupan sesuai nada yang sudah ditetapkan dengan sangat tepat.

Presentase hasil belajar siswa sebelum diberikan tindakan hanya 35\% yang tuntas setelah diberi penerapan model pembelajaran kooperatif tipe jigsaw menjadi $54,83 \%$. Namun hasil tersebut masih belum maksimal karena peningkatannya baru $19,83 \%$. yang mengalami ketuntasan. Itu artinya hanya separuh siswa dari 31 siswa yang mengalami ketuntasan hasil, maka perlu adanya tindakan siklus ke II untuk lebih memaksimalkan lagi.

$$
\text { Refleksi dilakukan dengan }
$$

menganalisi hasil belajar siswa untuk 
mengidentifikasi permasalahan, kelemahan, dan kesalahan yang terjadi dalam tiap siklus. Hal ini sesuai pernyataan Arikunto,(2015: 80) maksut dari tindakan ini yaitu untuk mengkaji secara menyeluruh tindakan yang telah dengan berdasarkan data yang terkumpul, kemudian dilakukan evaluasi guna menyempurnakan tindakan-tindakan berikutnya. Pernyataan tersebut dapat dilihat dari hasil penilaian akhir di kelas VIIB sebanyak 50\% siswa masih belum mencapai KKM yang telah di tentukan oleh lembaga sekolah, sehingga dalam penerapan model pembelajaran kooperatif tipe jigsaw akan di lanjutkan pada siklus II.

Pembahasan yang ada pada siklus II merupakan perbaikan dari pembelajaran tahap siklus I. Dalam tahapannya meliputi perencanaan, pelaksanaan, pengamatan dan refleksi. Masing-masing tahapan telah dijabarkan pada penerapan model pembelajaran kooperatif tipe jigsaw sebagai berikut:

Perencanaan pada kegiatan siklus II dilakukan berdasarkan dari hasil refleksi pada kegiatan siklus I untuk melakukan pembenahan pada siklus II. Dalam pembenahan pada siklus II di mulai dari pembuatan rancangan pelaksanaan pembelajaran baru. Perbedaan rancangan pelaksanaan pembelajaran dari siklus I di siklus II ada penambahan media pembelajaran berupa video dan pembenahan langkah-langkah pembelajaran berupa memaksimalkan tenaga ahli dalam menguasai materi. Menurut Arikunto (2015: 42) pengulangan dalam kegiatan siklus dilakukan dengan maksud melakukan pembenahan apabila penyajian metode baru belum baik, hal ini bertujuan untuk memantapkan metode yang sedang dicobakan agar diperoleh gambaran yang jelas.

Pelaksanaan pada siklus ke II lebih memaksimalkan model pembelajaran kooperatif tipe jigsaw, penggunaan media video dan partitur angka dengan lagu burung tantina yang kemudian di mainkan pada recorder.

Kegiatan dalam pelaksanaan disini sebelumnya guru menayangkan video tentang permainan alat musik recorder kepada siswa, setelah itu pembentukan kelompok yang terdiri anggota inti dan anggota ahli. Setiap anggota ahli diberikan materi berupa melodi, penjarian, tempo dan dinamika dalam memainkan lagu burung tantina. Anggota ahli berkumpul dengan anggota ahli baru untuk saling berdiskusi tentang materi yang sama. Setelah berdiskusi, setiap anggota ahli di tes untuk mempresentasikan materi yang sudah di pelajari kepada kelompok ahli yang lain dengan di bimbing oleh guru. Jika tenaga ahli sudah dinyatakan sudah menguasai dan bisa menyampaikan materinya, tenaga ahli bisa kembali kekelompok inti untuk menyampaikan materi yang sudah dipelajari. Menurut Sutijono, (2011:17) menyatakan bahwa pembelajaran kooperatif tipe Jigsaw adalah suatu tipe pembelajaran kooperatif yang terdiri dari beberapa anggota dalam satu kelompok yang bertanggug jawab atas penguasaan materi belajar dan mampu mengajarkan materi tersebut kepada anggota lain dalam kelompoknya.

Tahap siklus ke II mempelajari lagu burung tantina dengan alat musik recorder, karena pada pelaksanaan siklus I sudah mempelajari teknik dasarnya. Pengguanaan lagu sebagai pembelajaran praktik membuat siswa lebih mengembangkan kekreatifannya, tidak membuat bosan dan lebih memudahkan siswa dalam memahami materi. Sebagaimana dengan yang dikatakan oleh De Porter \& Hernacki (1992: 73) yang menyatakan bahwa musik berpengaruh pada guru dan siswa, guru dapat menggunakan lagu untuk menata suasana hati, mengubah keadaan mental siswa, dan mendukung lingkungan belajar siswa. 
Memaksimalkan model pembelajaran kooperatif tipe jigsaw pada siklus II ditambahkan media berupa video pembelajaran memainkan alat musik recorder agar lebih menginspirasi dan pemahaman yang sama kepada siswa dalam belajar alat musik recorder. Sesuai dengan Busyaeri (2016: 129) Manfaat media video untuk pembelajaran dapat mengembangkan imajinasi siswa, mampu berperan sebagai media utama untuk mendokumentasikan realitas sosial yang akan di bedah dalam kelas, dan dapat memancing kreativitas peserta didik dalam mengekspresikan gagasannya.

Perbandingan dari pengamatan siklus I di siklus II siswa lebih kondusif, aktif dan tertarik pada materi yang di bawakan oleh anggota ahli. Siswa menjadi bersungguh-sungguh dalam berlatih memainkan alat musik recorder. Hal ini juga dapat dilihat dari hasil akhir pembelajaran peraktek memainkan alat musik recorder dari empat aspek penilaian tentang penjarian, tempo, melodi dan kualitas suara yaitu hampir seluruh siswa mampu melakukan dasar penjarian alat musik recorder pada lagu burung tantina dengan sangat baik, siswa mampu mengikuti tempo dengan irama pada lagu burung tantina secara keseluruhan sampai akir lagu, siswa mampu memainkan melodi lagu burung tantinya dengan sangat lancar. Siswa mampu meniup recorder dengan kualitas suara tiupan sesuai nada yang sudah ditetapkan dengan sangat tepat.

Berdasarkan hasil sebanyak 28 dari 31 siswa dalam kelas VII-B telah tuntas dengan presentase ketuntasan $90,3 \%$ dan nilai ratarata kelas mencapai 79. Dari hasil tersebut dapat simpulkan peningkatan secara segnifikat dan pencapaian KKM dari siklus I. Tahap pengamatan merupakan salah satu cara pengumpulan data yang digunakan untuk mengetahui seberapa besar keberhasilan dalam penelitian. Menurut Arikunto dkk (2015: 222) untuk mendapatkan data yang akurat di butuhkan susunan instrumen yang valid dan raliabel.

Kegiatan refleksi siklus II dilakukan dengan mengamati dan mengkaji hasil data akhir nilai siswa dan dapat disimpulkan siswa berhasil dalam meningkatkan belajar praktik memainkan alat musik recorder. Dalam hal ini pelaksanaan pembelajaran dengan menggunakan model pembelajaran kooperatif tipe jigsaw mengalami peningkatan karena hasil belajar siswa pada siklus II lebih maksimal dari pada siklus I.

Berdasarkan peningkatan ketuntasan hasil ketrampilan dari siklus I sampai siklus ke II, maka peniliti menyudahi kegiatan penelitian model pembelajaran kooperatif tipe jigsaw di SMPN 1 Dau kabupaten Malang di siklus II. Menurut Arikunto (2015: 48) apabila tindakan sudah selesai dengan hasil yang lebih baik dari sebelumnya barulah tindakan bisa disudahi.

\section{Penutup}

Berdasarkan dari deskripsikan hasil pemabahasan dan penelitian, maka dapat diambil simpulan bahwa penerapan modep pembelajaran kooperatif tipe jigsaw pada siswa kelas VII-B SMPN 1 Dau kabupaten Malang dapat meningkatkan keterampilan siswa dalam materi memainkan alat musik recorder. Hal tersebut dapat ditunjukkan sebagai berikut:

Siklus I

Penerapan model pembelajaran kooperatif tipe jigsaw dalam pembelajaran Seni Budaya bidang Seni Musik pada siswa kelas VII-B di SMPN 1 Dau Kabupaten Malang mulai terjadi peningkatan dari pada sebelum menerapkan model pembelajaran kooperatif tipe jigsaw, namun dalam peningkatannya masih belum signifikan pada pelaksanaan pembelajaran siklus I. Berdasarkan hasil tersebut masih ada siswa yang belum tuntas atau belum meningkat sehingga dapat disimpulkan penerapan model pembelajaran kooperatif tipe jigsaw sudah mulai efektif tetapi masih kurang 
maksimal dalam pembelajaran Seni Budaya bidang studi Seni Musik. Terbukti dapat dilihat dari hasil belajar peserta didik pada siklus I sebanyak 17 siswa dengan persentase $54,83 \%$ telah tuntas melebihi nilai KKM (75) sedangkan sebanyak 14 siswa dengan persentase $45,16 \%$ belum mencapai nilai standart ketuntasan belajar.

Siklus II

Penerapan model pembelajaran kooperatif tipe jigsaw dalam pembelajaran Seni Budaya bidang Seni Musik pada siswa kelas VII-B di SMPN 1 Dau Kabupaten Malang sudah mulai mengalami terjadi peningkatan yang signifikan dari pada siklus I, hal ini dapat di artikan penerapan model pembelajaran kooperatif tipe jigsaw memang efektif dalam pembelajaran Seni Budaya bidang studi Seni Musik. Hal ini dapat dilihat Berdasarkan hasil akhir pembelajaran siswa yang lebih baik dari pada siklus I. Hasil belajar peserta didik pada siklus II hampir seluruh 31 siswa dalam satu kelas di VII B mengalami ketuntasan hasil belajar. Sebanyak 28 siswa sudah tuntas melebihi KKM (75) dengan presentase 90.3\%, sedangkan siswa yang tidak tuntas sebanyak 3 siswa.

Berdasarkan dari hasil kegiatan penelitian yang sudah dilakukan menunjukkan bahwa penerapan model pembelajaran kooperatif tipe jigsaw memberikan pengaruh yang cukup besar dalam meningkatkan hasil keterampilan peserta didik. Sehingga peneliti akan menyampaikan beberapa saran untuk dijadikan rekomendasi dan tindak lanjut dari penelitian ini.

Bagi guru diharapkan menerapkan model pembelajaran kooperatif tipe jigsaw dalam pembalajaran seni sebagai teknik penyajian materi untuk mengembangkan inovasi dan mempermudah penyampaian materi pembelajaran khusus pembelajaran seni musik.
Bagi siswa diharapkan dapat membangkitkan minat siswa dalam pembelajaran seni musik, memberikan kemandirian kepada siswa dan membuat siswa ikut berpartisipasi dalam pembelajaran, serta dapat memotivasi siswa untuk belajar aktif, dan kreatif .

Bagi sekolah diharapkan Hasil dari penelitian ini dapat dijadikan referensi dalam pengembangan dan peningkatan pembelajaran di sekolah secara umum, serta mutu pendidikan dalam keterampilan mengajar.

Bagi peneliti lain, diharapkan perlu adanya penelitian lanjutan dengan menggunakan model pembelajaran kooperati tipe jigsaw pada materi dan mata pelajaran yang lain dikarenakan penelitian ini masih dibilang terbatas pada materi bidang musik, hal ini agar dapat menambah variasi Penelitian tindakan kelas tentang model pembelajaran kooperati tipe jigsaw.

\section{Referensi}

Arikunto, Suharsini. 2015. Penelitian Tindakan Kelas. Jakarta: PT Bumi Askara.

Harini, N., \& Rahayuningtyas, W. (n.d.). 2018. Pembelajaran Tari Topeng Malang Melalui Media Teilerin Multimedia Interaktif.

Julianto, dkk. 2011. Teori dan implementasi model- model pembelajaran Inovatif. Surabaya: Unesa University Press.

Roestiyah N.K. 2008. Strategi Belajar Mengajar. Jakarta : PT Rineka Cipta.

Sukidin, Basrowi, Suranto. 2006. Cooperatif Learning di Sekolah. Bandung : PT Sinar Baru Algesindo.

Sutijono, dkk. 2011. Modul Umum Pendidikan dan Pelatihan Profesi Guru. Surabaya: Universitas PGRI Adi Buana.

Trianto. 2007. Model-Model Pembelajaran. Yogyakarta: Pustaka Book Publiser. 
10 ] Abdul Rozaq Fathin Khusairi, dkk.: Ketrampilan Memainkan Recorder Melalui Model Kooperatif

Zandra, R. A. (2014). Sejarah Musik

Keroncong di Surabaya. Imaji, 12(1).

Purnomo, Wahyu. 2009. Terampil Bermusik.

Surakarta: CV. Putra Nugraha. 